\title{
Georges Perec and the Significance of the Insignificant
}

\section{Ben Highmore}

Georges Perec died in 1982 at the age of 45 . What is he for us now, 33 years later in the second decade of the twenty-first century? How do we make him our contemporary? To make Perec's work part of our present-day involves (perhaps counter-intuitively) grasping his project in its historical specificity. It isn't by cherry-picking useable aspects of the work that we will ensure some relevance to its afterlife: rather it will be by recognising his larger project as a response to a particular historical situation. While Perec's situation in the 1960s and 70s in France is not ours, it has its hooks in our world. Perec, I think, becomes our contemporary in the act of seeing those hooks, of seeing how a continuity of feeling and mood percolates through historical ruptures, and how changes in mood and feeling activate historical continuities.

There is a simple claim driving this essay, namely that a central aspect of Perec's project was its attempt to register actuality. Which is to say that his project was a form of realism and like many forms of realism it was a quest and a question rather than an answer or solution. And as a question Perec's realism goes something like this: in a situation where there is no specific artistic style that has a privileged access to reality; where scholarly disciplines are all trying to grasp their slice of reality and claim it as the reality; and where the real is saturated by the unreality of the commodity spectacle - how can realism be achieved? Or slightly differently, and now as a quest rather than a question: if the means of grasping reality (from literature to sociology, from religion to politics) are in doubt, and if, because of this, there is a suspicion about what in the world should count as significant, then realism might mean revealing the significance of the insignificant.

Perec's work is full of lists of objects and activities, of itemised occurrences and repeated gestures. And it is also a constant puzzling and worrying about what to include as 
part of these itineraries and what to ignore. A crucial worry is that what presents itself as significant (intention or motivation, say, or political and national events) bears the mark of a doxa - an unquestioned assumption of value that reproduces a social order. But Perec's worry doesn't end there, in fact this is its beginning. Suspicion and refusal of the doxa isn't in itself a freedom or a liberation: it offers only an unedited (or un-editable) reality, a mêlée without shape or end. Without some form of commitment to politics say or to the protocols of an analytic approach what reason could there be for focusing on one thing rather than another, of attending to $\mathrm{x}$ while discounting $\mathrm{y}$ ? Or more crucially, as his onetime teacher Roland Barthes articulated it, without opting for a position, description is endless, inexhaustible: 'if it were not subject to an aesthetic or rhetorical choice, any "view" would be inexhaustible by discourse: there would always be a corner, a detail, an inflection of space or color to report.' 1

Acknowledging the world as inexhaustible is a central aspect of Perec's work in the 1970s, particularly in the project published as An attempt at exhausting a place in Paris (first published in French in 1975). ${ }^{2}$ But while this short book might declare its intention to provide an exhaustive description it actually articulates all the conditions that make such a project impossible. And it is in the impossibility of the project, and in the waywardness of the descriptions of what is perceived and imagined that Perec offers us a realism engaged not just in describing reality but in describing the activity and limitations of attending to and describing reality. The attempt at exhausting takes place over three days at various cafés in Place Saint-Sulpice and starts out by very quickly itemising the buildings, shops, the church, the statue and fountain in the large square. Instead of concentrating on these elements that could be described as already-marked-as-significant (part of a tourist itinerary, or a list of retail outlets and eateries, and so on), Perec seeks 'to describe the rest instead: that which is generally not taken note of, that which is not noticed, that which has no importance; what happens when nothing happens other than the weather, people, cars, and clouds. ${ }^{3}$ He notes the buses that pass and the different kinds of movement involved in navigating the place: 'waiting, sauntering, dawdling, wandering, going, running toward, rushing (toward a free taxi, for instance), seeking, idling about, hesitating, walking with determination'. 4

An attempt at exhausting a place in Paris isn't just a valiant effort to attend to the insignificant it is also registers the necessary contingencies involved in this. So for 
instance while watching a bus arrive you miss a car parking: 'Obvious limits to such an undertaking: even when my only goal is just to observe, I don't see what takes place a few meters from me: I don't notice, for example, that cars are parking'. ${ }^{5}$ Boredom and the exhaustion of the observer is also another factor that limits any attempt to exhaust the place: 'Buses pass by. I've lost all interest in them. ${ }^{6}$ A problem that accompanies this is repetition: if what you are witnessing is a constant stream of passing passers-by how often do you register this?

I again saw buses, taxis, cars, tourist buses, trucks and vans, bikes, mopeds, Vespas, motorcycles, a postal delivery tricycle, a motorcycle-school vehicle, a driving-school car, elegant women, aging beaus, old couples, groups of children, people with bags, satchels, suitcases, dogs, pipes, umbrellas, potbellies, old skins, old schmucks, young schmucks, idlers, deliverymen, scowlers, windbags. ${ }^{7}$

If exhaustion is the aim would you need to describe each and every vehicle? Or is it enough to say that there was a fairly constant stream of foot traffic and road traffic? And how much should description include? As soon as adjectives are introduced the flat itemising of objects becomes something closer to interpretation: these women are elegant, those people look like windbags. As itemising accumulates you can hear the echo of frustration, of a creeping misanthropy that emerges out of the Sisyphean task of exhausting description.

Realism, then as now, involves a politics because it stakes a claim on an always contested reality (is reality harmonious or fractious, class-bound or meritocratic, for instance?). ${ }^{8}$ But literature (or art more generally) is not the privileged province of realism. Indeed it would be hard to think of the varieties of realism within the literature of modernity outside of the realism claims made by sociologists, anthropologists, political economists, psychologists, historians, biologists, and so on. Take, for example, Georg Lukács' claims for realism in his book The Meaning of Contemporary Realism (first published in German 1957, translated into French and English in the early 1960s). Lukács' book promotes a version of critical realism that is set against versions of naturalism (avantgarde and conventional). The key to critical realism, for Lukács, is that the particularity of a character, of a plot, of a situation and an environment reveals its relationship and position 
within a larger orchestration of the totality, and in doing so offers a critical (because it is particular, because it necessarily provides an angle) view of that totality. Realism here requires that the details of the particular are significant details for the totality:

But whether or not the sequence and organization make for an adequate image of objective reality will depend on the writer's attitude towards reality as a whole. For this attitude determines the function which the individual detail is accorded in the context of the whole. If it is handled uncritically, the result may be an arbitrary naturalism, since the writer will not be able to distinguish between significant and irrelevant detail. $^{9}$

The 'arbitrary naturalism' that Lukács points at would include the sort of psychological naturalism (invoking a character's inner voice as a 'stream of consciousness', for instance) of modernist writers such as Virginia Woolf or James Joyce.

What is at stake in disparaging psychological naturalism while promoting a critical realism aimed at unveiling the way that social structures affect and effect lives (a realism based on the way that a singularity of the detail offers access to the generality of the social) is not just a question of style. It is a question of intellectual heritage, socio-political analysis, and investigative priorities and propensity. While the 'arbitrary naturalism' of Woolf and Joyce, for instance, might be seen as a reaction against a previous tradition of literature (most obviously, for Woolf, the work of a writer such as Arnold Bennett) it also (and generatively) needs to be seen as aligning itself with an investigative concern found in the work of people such as William James and Bertrand Russell. ${ }^{10}$ Similarly the world of Lukács is unthinkable outside the investigative interests articulated by Marx and Engels, Luxemburg, and Hegel.

In the early 1960s Perec's position was broadly aligned with Lukács'. Indeed Perec's important essay 'For a Realist Literature' (1962) pursues a position very close to Lukács' in The Meaning of Contemporary Realism. Fundamentally, for Perec, the artwork, by offering an orchestration of the world, provides a coherent depiction:

What we call an artwork isn't just the rootless creation that the aestheticist work is; on the contrary, it is the most total expression of concrete realities; if literature is a 
work of art, it is because it organizes and unmasks the world, because it makes the world appear in its coherence beyond its everyday anarchy, while integrating and surpassing the contingencies that render it in the form of the immediate system, with its necessity and its movement. ${ }^{11}$

The methodological basis of this position is a dialectical movement between the general and the particular:

Because the particular only appears as a function of the general, and because the general can only be grasped as a function of the particular, this self-conscious effort [to write in order to know oneself] that remains a point of departure for all creation (literary or not) can only be a point of departure, and remains useless if it doesn't integrate itself into a larger project involving reality in its entirety. ${ }^{12}$

For Perec, then, realism is the struggle against the formlessness of 'everyday anarchy'. Its role is to find the general in the particular through the seemingly tautological route of recognising that the general can only function in its particularities.

Does this fit with the image we have of Perec? Don't we normally think of Perec as embracing the 'everyday' (and its potential for anarchy) against a (false) coherence offered by conventional narrative forms or by a political interpretation of society? ${ }^{13}$ Doesn't the usual account of Perec suggest that his leftist political leanings became less important in his work, as his work became more ludic in form? Against this I want to argue that the relationship between the particular and the general, or the detail and the totality, is one that was foundational in his work. But it was a relationship that was unreconciled and led to an experimental approach to the registering of everyday life.

The question that Perec's work poses is centred on the details of everyday life, and how such details might be meaningful or sensible within a larger social world. What Perec shares with Lukács is a critique of aspects modernist literature that simply revel in the anarchy of the everyday (in forms of psychological naturalism) and see these as disconnected fragments tied to a monadic understanding of the world. He also seems to recognise in Lukács' writing the importance of realism for attending to moments of dynamic social change. In the late 1950s Lukács' realism offered a route between the 
asocial, hyper-modernism of the Nouvelle Roman (as represented particularly by Alain Robbe-Grillet and Nathalie Sarraute) and the instrumentalism of Jean Paul Sartre's committed literature. But Lukács wasn't the only theoretical voice he was listening to. Indeed in the way that he navigates across the dilemma of the relationship between the particular and the general his position is perhaps closest to the work of the Marxist philosopher and sociologist Henri Lefebvre.

In 1958 while Perec was undertaking his National Service (as a parachutist) he stayed with Lefebvre at the philosopher's home in Navarrenx. ${ }^{14}$ Lefebvre had just published the second edition of his Critique of Everyday Life with the addition of a hundred-page 'Foreword' that clarifies and theoretically develops his understanding of everyday life within capitalist society (which he had first theorised in the 1930s). Indeed across all the texts that Lefebvre wrote on everyday life it is this 1958 'Foreword' that is the most important in establishing the potential and the problematic of everyday life for critical thinking. In it he offers a definition of everyday life:

Everyday life, in a sense residual, defined by 'what is left over' after all distinct, superior, specialized, structured activities have been singled out by analysis, must be defined as a totality. Considered in their specialization and their technicality, superior activities leave a 'technical vacuum' between one another which is filled up by everyday life. Everyday life is profoundly related to all activities, and encompasses them with all their differences and their conflicts; it is their meeting place, their bond, their common ground. ${ }^{15}$

For Lefebvre modernity produces the everyday, but not as an integrated realm of the social that is open to reflection, contemplation and public discussion. Instead it produces it as an unmanaged remainder, that provides (potentially at least) a royal road to the totality. This remainder is produced, partly, through an extensive parcelling-out of daily experience into a host of institutions and expertise: to psychology, sociology, to literature, to health, to professional leisure activities, to social surveys, and so on. The everyday falls between the cracks of such specialisation.

The methodological outcome of Lefebvre's critique is a refashioning of Lukács rendering of the particular and the general. For Lefebvre the general is still ultimately 
important but the only way to access it is through the social detail - the everyday. In Lukács the methodological imperative seems to be that the social totality (the general) decrees what would be significant or not. With Lefebvre the understanding is that everything is significant in as much that it contains (like a fractal) the imprint of the general. He gives the example of a woman buying some sugar to show how a small everyday event connects to history, global trade, and memory, and that all this is there in the details of everyday life:

Although what I grasp becomes more and more profound, it is contained from the start in the original little event. So now I see the humble events of everyday life as having two sides: a little, individual, chance event - and at the same time an infinitely complex social event, richer than the many 'essences' it contains within itself. $^{16}$

If everything is touched by the totality because nothing is ultimately autonomous, then what makes Lefebvre opt for one example over another? In theoretical terms there wouldn't be a privileged realm for moving from the particular to the general, but in pragmatic terms there would be very good reasons for not fixing on the sorts of objects and practices that are already seen as significant by those forms of specialisation that remainder the everyday. Indeed it would be by purposefully seeking out the details of everyday life, details that haven't already been marked as significant that investigation can, for a while at least, avoid the doxa of established specialism with their alreadymarked-as-significant objects. In this way the insignificant provides a trajectory aimed at a totality-yet-to-be-perceived, rather than one known in advance. The insignificant (which is always in danger of becoming the new significant) is a heuristic device for exploring emergent generalities and totalities-in-transformation. This is, I want to suggest, what drives Perec's work. I have already briefly looked at the observational work that he conducted in the 1970s but it is perhaps most deliberately explored in his novel from 1965, Things: A Story of the Sixties. 
In Kristin Ross' Lefebvrian cultural history of the decade from the mid-1950s to the mid-

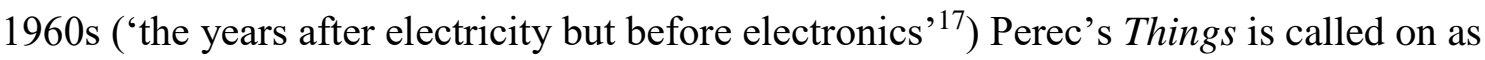
an important cultural witnesses to the changes that France is undergoing. For Ross, French postwar modernisation, particularly evident in the growth of a consumer culture, isn't a slow series of adjustments, it is a pell-mell social reordering and re-orchestrating:

In the space of just ten years a rural woman might live the acquisition of electricity, running water, a stove, a refrigerator, a washing machine, a sense of interior space as distinct from exterior space, a car, a television, and the various liberations and oppressions associated with each. ${ }^{18}$

In Ross' account Perec's novel is used to show the way that the child-free heterosexual couple becomes a sign of a new unit of consumption and a new class experience. Things, we could say, explores a new territory of consumer culture as it constitutes a crucial aspect of class culture and class experience. This isn't class culture already fashioned in the caldron of industrialisation (a class already known through established forms of significance) it is an emerging class fashioned out of changes in market capitalism, changes in media, changes in the relations of production and consumption, and changes in the nature of work.

Things describes the lives of Jérôme and Sylvie by detailing their material circumstances: their apartment, their work, their furniture and clothes, the food they consume, their groups of friends, their nights out, the films they watch, and the magazines they read. Yet for all that Jérôme and Sylvie aren't individuated by this extensive itemisation, rather they become generalised in their particularity. They are part of a milieu and are, for us as readers, representatives of this milieu. As the book states:

They were the 'new generation', young executives who had not yet cut all their teeth, technocrats on the way, but only halfway, to success. Almost all of them came from the lower middle classes, whose values, they felt, were for them no longer adequate. They cast their eyes enviously, desperately, towards the visible 
comfort, luxury and perfection of the upper middle classes. They had no past, no tradition. There were no inheritances to wait for. ${ }^{19}$

If some expertise was useful for registering this class, it was an expertise that had some agency in fashioning groups as visible entities and as class positions. Exponents of this new knowledge went by the name of psychosociologues (psychosociologists) or market researchers in Britain and America. During 1960 Perec worked as a market researcher for the Dutch electronics firm Philips and for the cosmetics company L'Oréal. ${ }^{20}$ Market research effected a feed-back loop that allowed promoters to shape commodities so as to feed emergent desires and to fashion a subject (a targeted consumer) for these commodities. Market research, then, was a flexible 'social science' with a heightened ability to discover the emergent and produce consumer-class identities based on a liking for such things as high-modernist furniture or Shaker-style kitchen units, or both.

In the novel Jérôme and Sylvie are both market researchers canvasing opinion about 'students, fingernails, cough syrup, typewriters, fertilisers, tractors, leisure pursuits, presents, stationery, linen, politics, motorways, alcoholic drinks, mineral water, cheeses, jams, lamps and curtains, insurance and gardening. ${ }^{21}$ In their work Jérôme and Sylvie feed the world of commodity production in a direct manner, but Things is a story that is focused on how a milieu (a milieu that is also Perec's milieu to a certain degree) becomes constituted as consumers. And here the world of commodity promotion is not just tied to the advertising industry but seen as diffuse, saturating the life-world of a milieu as a vague set of names, moods, feelings, and objects. In clothing it marks a trajectory of class aspiration and class individuation that could mark and make subjects as they pass from adolescence into consumer-adulthood. Initially Jérôme and Sylvie dress like students, but gradually they attire themselves in textures and textiles that conjure-up a rich imaginary of values and sensual arrangements: 'knitwear, silk blouses, shirts by Doucet, cotton voile ties, silk scarves, tweed, lambswool, cashmere, vicuna, leather and jerseywool, flax and, finally, the great staircase of footwear leading from Churches to Westons, from Westons to Buntings and from Buntings to Lobbs. ${ }^{22}$ Needless to say such a trajectory has no endpoint - there is always a further step on the 'staircase of footwear'.

One of the central arenas for disseminating cultural imaginaries of material culture was the burgeoning magazine industry, particularly magazines such as $L$ 'Express and 
Madame Express. ${ }^{23}$ Perec 'wrote Things with a pile of Madame Express beside me, and, to wash my mouth out after having read rather too much Madame Express, I would read some Barthes. ${ }^{24}$ The new 'lifestyle' magazines offered objects and opinions, holidays and menus:
L'Express held out to them all the signs of comfortable living: thick bathrobes, brilliant unravellings of murky truths, fashionable beaches, exotic cookery, useful tips, intelligent news analysis, the secrets of the gods, places out in the sticks where you could pick up property for almost nothing, the names of the different carillon bells, new ideas, smart outfits, frozen food, elegant accessories, the scandals of polite society, up-to-the-minute advice. ${ }^{25}$

Such magazines, like the world of market research, had a dual role to play, both pandering to the interests of new class identities and concerns, while also bringing that class and its imaginaries into material being. They also emphasised the gap between dream and reality, desire and actuality, through their constant juxtaposition of unspoilt beeches and war reporting, fashion spreads and social exposés. The lifestyle magazine itself was a mobile media well-fitted to other changes in society. According to Kristin Ross:

The growth of the magazine industry after the war bears some relation to the expansion under capitalism of what Lefebvre calls 'constrained time': in this case, the frequent periods of waiting or transition - appointments, commuting - that break up a day and which the portable format, easily digestible prose, and manageable article length of a magazine help fill. ${ }^{26}$

The precarious work of a market researcher (or other service sector workers), with long commutes to different locations was well-suited to the sort of intermittent and mobile reading experience of magazines.

Things is fashioned out of a couple (Jérôme and Sylvie), a world of work (the casualized employment of market researchers), a medium (lifestyle magazines) and a vast array of material cultural items. It embodies Perec's insistence on describing the world materially rather than imputing an interiority to characters: 'I detest what's called 
psychology... I prefer books in which characters are described by their actions, their gestures, and their surroundings. ${ }^{27}$ But if we usually think of this interiority as the place for such things as beliefs and values, identifications and desires, Perec seems to suggest that we can find them more materially through attending to the prosaic world of everyday material actuality. In this his work has the feeling of it being empirical research. In its description of a class - what in France was being called technocrats or 'hyper-pettybourgeois $^{28}$ - Things describes class not as an identification, or a heritage, but as a daily material practice.

In the France of the 1950s and 1960s the emergence of the 'new middle classes' was a symptom of the staggering changes taking place within homes, within working environments and within global relations (decolonization and what Lefebvre called neocolonialism). Writing a few years after Things Lefebvre sees these changes resulting, not in the eradication of the working-class, but in a new class relation to the totality via consumerism:

For work and for the worker as subject (individual and collective) the consumer has been substituted who is no longer a subject but a place, that of consumption. Who speaks? The one who teaches consumption, the advertiser, the organizer of the everyday, the one who initiates the coincidence of the image and the situation, between the ideal and the real. To whom does one speak? To the consumer. To his ideal. When one speaks 'to me' it is not to me but to the possible consumer, the ideal... ${ }^{29}$

Consumerism obscures class relations as well as establishing new class identities and moods. And it is this obscurity that produces a crisis in political identity. In Perec's Things, political commitments are worn like clothes, liable to wear-and-tear and to the built-in obsolescence of fashion. Politics has to cope with a new set of allegiances to material life. This is how Perec describes it for the milieu of Jérôme and Sylvie:

In the past men fought in their millions, and millions still do fight, for their crust of bread. Jérôme and Sylvie did not quite believe you could go into battle for a chesterfield settee. But that was all the same the banner under which they would 
have enlisted most readily. There was nothing, they thought, that concerned them in party manifestos or in government plans: they would sneer at early retirement pension schemes, increased holiday entitlements, free lunches, the thirty-hour week. They wanted superabundance - Garrard turntables, empty beaches for their eyes only, round-the-world trips, grand hotels. ${ }^{30}$

In concentrating on a material world of what, in the literary and academic world of the 1960s, would have been considered 'insignificant' Perec (and Lefebvre) manage to articulate a general social world that urgently required a new political imaginary. Perec, though, was not the sort of political animal who would work to devise such an imaginary. His work was diagnostic and descriptive. By starting out with insignificant details (fitted carpets, Garrard turntables, chesterfield settees), Perec fashioned a novel of thickdescription that offered a semiotics of the totality:

What I wanted [...] was for my words to be 'injected' with meaning, loaded with resonance. Fitted carpet, for instance: for me, that phrase conveys a whole system of values - specifically, the value-system imposed by advertising. So much so that you could say that, in places, my book is a piece of advertising copy; but, obviously, with distance, and with irony that distance brings. The words I use do not designate objects, or things, but signs. They are images. Things is a story of poverty inextricably tangled up with the image of wealth. ${ }^{31}$

I think that Perec undervalues the materiality of the things he itemises in his novel. In this he was not alone. This was after all the period when semiology was at its peak. His desire to have phrases like 'fitted carpet' resonate with meaning is precisely the desire to move from the detail to the totality, from the insignificant everyday to the social.

To fashion the general out of the insignificant required that Perec supplement his interest in Lukács' ideas of contemporary realism with ideas percolating through from Roland Barthes and Henri Lefebvre. In recognising the significance of the insignificant in such items as fitted carpets and chesterfield settees, the insignificant is used as a heuristic tool for accessing the social as an emergent form. To see the insignificant as a heuristic methodology Perec had to side with the everyday against an already established 
understanding of what constituted significance within a known totality. It was by foregrounding the insignificant detail that the social had a chance of becoming visible as an emergent form.

\section{AFTERLIVES}

A few years after Perec published Things the anthropologist Paul Rabinow was undertaking his doctoral fieldwork in Morocco. Roughly a decade later he published a book reflecting on the practices of fieldwork. Trained in the social sciences at the University of Chicago, and well-versed in the structuralist anthropology of Claude LéviStrauss, Rabinow went to urban and rural Morocco in search of symbolism and ritualistic activities through which Moroccan culture could be interpreted and understood. But his reflections are aimed instead at the day-to-day activity of interacting with his 'informant' and friend Ali. Rabinow's reflections are about a frustration with the doxa of anthropology (symbolic ritual) and its lack of interest in the much less exotic world of humdrum everyday life. For Rabinow an argument with Ali, reveals just how little he understands of Ali's day-to-day world:

It is in the less explicitly shaped and less overtly significant areas of day-to-day activity and common-sense reasoning that most cultural differences are embedded. Thematic observation is disturbingly difficult, for these phenomena are everywhere, thereby proving the most opaque to the methodologies we have developed. There are no clear boundaries to conclusively limit and define cultural performance. Ritual certainly has its complexities, but they are of a different order from those more scattered, fragmentary, and partial orderings which give coherence to social life. ${ }^{32}$

For Rabinow cultural ritual, the lingua franca of anthropological fieldwork, offered an 'official' interpretation of culture; ritual, in a strong sense, was culture already interpreted, packaged and ripe for consumption. Ritual already knew what was significant and declared it in advance. For an anthropologist ritual was the doxa of investigation, against which the 
'scattered, fragmentary, and partial' orchestrations of the everyday seemed less significant, or even insignificant.

Like Rabinow, Perec (and those with an interest in everyday life) opt to side with the insignificant against that which is already-marked-as-significant. To do so in the name of literature is to plunder to vast terrain of detail that fashions conventional forms of realism without necessarily directing its narrative drive:

The singularity of description (or of the 'useless detail') in narrative fabric, its isolated situation, designates a question which as the greatest importance for the structural analysis of narrative. This questions is the following: Is everything in narrative significant, and if not, if insignificant stretches subsist in the narrative syntagm, what is ultimately, so to speak, the significance of this insignificance? $?^{33}$

Perec excavates insignificant stretches of the life-world and makes them his literary terrain. It produced literary forms that reveal the significance of the insignificant. To do this the foregrounding of the everyday can only be an initial move. Simply to recognise the significance of the insignificant is not enough. The insignificant is inexhaustible and it is formless. The insignificant guards against the doxa of the already-marked-as-significant. But the insignificant is also a lure that invite forms of passive naturalism, or more simply a sort of aimless and endless itemising. What is also needed is a position, a set of limitations, a project.

For Perec these limitations and the project that went with them changed over the years. In an interview from 1981 he connects the mathematical and ludic limitations that Oulipo (the group of experimental writers he belonged to) sought to encourage not to forms of avant-gardism but to the much longer history of tradition literature reaching back to forms such as the tanka in Japanese poetry or the alexandrine in European poetry of the baroque and early modern periods. For Perec the anarchy of modernism broke the formal limitations of literature producing what Lukács saw as arbitrary naturalism. Limitations needed to be imposed so that the everyday didn't result in the refusal of social form: 'Now we are obliged to find new forms, new ways of tracing our way through that thing which is so opaque. ${ }^{34}$ If the insignificant protected writing from the doxa of the disciplines 
(including literary disciplines) then formal limitations guarded again the endlessness of the everyday detail.

To shift from a sense of knowing what is significant (what should be studies) and to opt instead for a more heuristic foregrounding of the insignificant and everyday is connected to a history that is played out both at the level of ideas (the rise of doubt and suspicion, the belief in knowledge-from-below) and at the level of material actuality (a revolution in communication and technology, a exponentially expanding consumer culture, a superabundance of opportunities for individuating selves, and so on). Perec's historical moment is both ours and not ours. Were we to conduct Perec's experiments now (for instance the Attempt at exhausting...) mobile communication technology would alter both the reality we set out to describe and our attempts at describing it. If the place that Perec describes is a nexus of cars and buses and people who are passing through, such a phenomenological investigation is rendered more complex still when we consider the possible other places that they are also moving through via their wireless communication devices. Similarly the boredom that befalls the observer in the early 1970s would also have to confront the temptations and habits we have established as electronic twitches around such everyday mobile devices. And what would Things look like if it was a story of the 2010s rather than the 1960s? Would it be so thingly? What would be the role of the internet? How might leisure have changed? And obsessions about bodies and health?

If Perec's time isn't quite ours it certainly offers a foretaste of our present day world of endless opportunities to consume (and to consume ideas and opinions as much as shoes and furniture), and where such consumption obscures other possible connections of identity and politics. Perec provides an epistemological invitation that is still key to trying to grasp the details of everyday life as a critical opportunity. It is in his declensions of doubt and belief, of the relationship we have with consumer culture and our desires for a better life, that Perec is still our contemporary.

\section{References:}

Theodor Adorno, et al., Aesthetics and Politics (London: Verso, 1980). 
Judith Attfield, Bringing Modernity Home: Writings on Popular Design and Material Culture (Manchester: Manchester University Press, 2007).

Ann Banfield, The Phantom Table: Woolf, Fry, Russell and the Epistemology of Modernism (Cambridge: Cambridge University Press, 2000).

Roland Barthes, 'The Reality Effect', The Rustle of Language (Oxford: Blackwell, 1986), pp. 141-8 [originally published in French in 1968].

David Bellos, Georges Perec (London: Harvill Press, 1999)

Peter Brooks, Realist Vision (New Haven: Yale University Press, 2008)

Andrew Leak, 'Phago-citations: Barthes, Perec, and the Transformations of Literature', The Review of Contemporary Fiction, 13, 1 (1993), pp. 124-147.

Andrew Leak, 'Paris: Created and Destroyed', AA Files, 45/46 (2001), pp. 25-31.

Henri Lefebvre, Critique of Everyday Life: Volume 1, translated by John Moore (London: Verso, 1991).

Georg Lukács, The Meaning of Contemporary Realism, translated from the German by John and Necke Mander (London: Merlin Press, 1963) [published in German in 1957].

Colin McDonald and Stephen King, Sampling the Universe: The Growth, Development and Influence of Market Research in Britain since 1945 (London: NTC Publications, 1996).

Joe Moran, 'Mass-Observation, Market Research, and the Birth of the Focus Group, 19371997’, Journal of British Studies, 47, 4 (2008), pp. 827-851. 
Linda Nochlin, Realism (London: Penguin, 1971).

Georges Perec, Things and A Man Asleep (London: HarperCollins, 1990) [Les choses originally published in French in 1965].

Georges Perec, 'For a Realist Literature', Chicago Review, 54, 3-2 (2007), pp. 28-39 [originally published in France in 1962].

Georges Perec, 'Lieux: Four texts by Georges Perec', AA Files, 45/46 (2001), pp. 32-77.

Georges Perec, An attempt at exhausting a place in Paris (Cambridge MA: Wakefield Press, 2010 [originally published in 1975].

Georges Perec and Kaye Mortley, 'The Doing of Fiction', The Review of Contemporary Fiction, 13, 1 (1993), pp. 94-101.

Mark Poster, Existential Marxism in Postwar France: From Sartre to Althusser (Princeton: Princeton University Press, 1975).

Paul Rabinow, Reflections on Fieldwork in Morocco (Berkeley: University of California Press, 1977)

Bryony Randall, Modernism, Daily Time and Everyday Life (Cambridge: Cambridge University Press, 2011).

Kristin Ross, Fast Cars, Clean Bodies: Decolonization and the Reordering of French Culture (Cambridge, MA: MIT Press, 1995).

Bio:

Ben Highmore is Professor of Cultural Studies at the University of Sussex. He is currently working on the relationships between taste, retailing, art and design, and domestic life as 
part of a research fellowship for the Leverhulme Trust. His most recent book is The Great Indoors: At Home in the Modern British House (Profile Books 2014). Previous books include Ordinary Lives: Studies in the Everyday (Routledge 2011) and A Passion for Cultural Studies (Palgrave 2009).

\footnotetext{
${ }^{1}$ Roland Barthes, 'The Reality Effect', p. 145.

${ }^{2}$ The book should be seen as part of a much larger project that Perec eventually gave up. Had it been completed it would have resulted in 288 different texts that would describe (half from memory, half from onsite observation) twelve different places in Paris written over twelve years (at the rate of two texts per month). See Andrew Leak, 'Paris: Created and Destroyed' and Georges Perec, 'Lieux: Four texts by Georges Perec'.

${ }^{3}$ Perec, An attempt at exhausting a place in Paris, p. 3.

${ }^{4}$ Ibid, p. 10.

${ }^{5}$ Ibid, p. 10.

${ }^{6}$ Ibid, p. 29

${ }^{7}$ Ibid, p. 18.

${ }^{8}$ The literature on realism is excessive. For a general introduction to realism see Linda Nochlin, Realism and Peter Brooks, Realist Vision. The important debates around realism that took place in the 1920s and 30s in Germany are well-represented in Adorno et al, Aesthetics and Politics.

${ }^{9}$ Georg Lukács, The Meaning of Contemporary Realism, translated from the German by John and Necke Mander, London: Merlin Press, 1963 (originally published in 1957).

${ }^{10}$ See Ann Banfield's The Phantom Table, Liesl Olson, Modernism and the Ordinary, and Bryony Randall's Modernism, Daily Time and Everyday Life for useful discussions of the role played by various forms of philosophy and psychology in modernist literature.

${ }^{11}$ Georges Perec, 'For a Realist Literature', p. 32.

12 Ibid, p. 33

${ }^{13}$ Michael Sheringham's Everyday Life: Theories and Practices from Surrealism to the Present offers the most detailed account of Perec's relationship to 'everyday life' within a French intellectual context.
}

${ }^{14}$ See David Bellos, Georges Perec: A Life in Words, p. 192. Lefebvre also introduced Perec to the work of Marcel Mauss, and helped Perec get work as a market researcher.

${ }^{15}$ Henri Lefebvre, Critique of Everyday Life: Volume One, p. 97.

${ }^{16}$ Ibid, p. 57.

${ }^{17}$ Kristin Ross, Fast Cars, Clean Bodies, p. 2.

${ }^{18}$ Ibid, p. 5. 
${ }^{19}$ Georges Perec, Things, p. 50

${ }^{20}$ Bellos, Georges Perec, p. 215. For the importance of market research in Britain see Moran 'MassObservation, Market Research, and the Birth of the Focus Group, 1937-1997' and McDonald and King, Sampling the Universe.

${ }^{21}$ Georges Perec, Things, p. 38-9.

${ }^{22}$ Ibid, p. 39.

${ }^{23}$ These are magazines that in the 1960s combined lifestyle advice with social issue articles. In Britain the equivalent would be a magazine like Nova as well as the colour-supplement magazines that started to appear with Sunday papers in the early 1960s.

${ }^{24}$ Perec cited in Andrew Leak, 'Phago-citations: Barthes, Perec, and the Transformations of Literature', p. 133. Perec was always asserting the importance of Barthes for his work in the 1960s. If he underplayed the importance of Lefebvre it is probably because it was more diffuse in his work.

${ }^{25}$ Perec, Things, p. 47.

${ }^{26}$ Kristin Ross, Fast Cars, Clean Bodies, p. 143.

${ }^{27}$ Perec cited in the introduction to Thoughts of Sorts, p. x.

${ }^{28}$ Poster, Existential Marxism in Postwar France, p. 217.

${ }^{29}$ Henri Lefebvre, writing in 1967 in the book, Position: contre les technocrates cited in Poster, Existential Marxism in Postwar France, p. 253.

${ }^{30}$ Perec, Things, p. 77

${ }^{31}$ Marcel Bénabou and Bruno Marcenac, 'Georges Perec Owns Up: An Interview' [December 1965], in The Review of Contemporary Fiction, 13, 1 (1993), p. 28. A good deal of what Perec writes about in Things is relevant to a more general European context. For the British context of fitted carpets see Judith Attfield, Bringing Modernity Home, chapters 8 and 11.

${ }^{32}$ Rabinow, Reflections on Fieldwork in Morocco, p. 58.

${ }^{33}$ Roland Barthes, 'The Reality Effect', p. 143.

${ }^{34}$ Georges Perec and Kaye Mortley, ‘The Doing of Fiction', p. 96. 